\title{
The Ecomomic Impact of Agricultural Products in the Albanian Exports
}

\author{
M. Sc. Eda Bezhani, Ph.D. Candidate \\ Lecturer, "Aleksander Moisiu" University, Durres, Albania \\ Email:_edabezhani82@gmail.com
}

Doi:10.5901/ajis/2013.v2n1p263

\section{Abstract}

Exports are considered as one of the priorities of government for the developing of the economy and facing the trade liberalization process of Albania in the international market. The increasement of exports is one of the most fundamental indicators for increasing the competitiveness in the economy, the increase of investors and one of the indicators for increasing the employment in Albania. The performance of the economy in these years has been characterized in quite large fluctuations in its stability, restructuring, growth rate and in this way of huge transformations. This kind of performance has accompanied also that part of exportoriented economy by turning the economy and the domestic market to a market economy that is relied mainly on imports. Based on the Intermediate Interim Agreement on the I-December 2006, it is expected a significant impact on domestic economic structure. Due to this agreement the export tariffs will decrease faster than those of imports. This is expected to have a positive effect because in the EU countries perform about $60 \%$ of imports and $80 \%$ of exports ${ }^{I}$. Because of the rapid expansion of exports and moderate growth in imports, there has been an improved trade deficit, helping to balance the demand and supply for foreign currency and to maintain the national currency ${ }^{2}$. Exports during the first 8 months of the year increased 25 billion ALL compared with the year 2010. Domestic Exports includes the agricultural products (medicinal plants, tobacco), by metals (ferrochrome and aluminum), leather, from timber and mineral products (fuels). Exports of agricultural products include all countries in the region, but we are also exporting to Hungary, Germany and other countries of the European Union.

Keywords: Exports, agricultural products, agricultural marketing.

\section{Introduction}

"Export growth is important because of its effect on internal trade and economic stability. Even more, the rate of economic growth and the distribution of income and wealth in a country are closely related to export growth."

By the given statistical data is observed that the export-import ratio in years has varied almost at the same levels I:9 (export-import).

\footnotetext{
${ }^{\text {I }}$ Strategy and business development investments (2007-2013)

${ }^{2}$ Monetary Policy Report, April 201 I
} 
Table I: Exports and imports in agro-food industry and trade balance (in Million Euro)

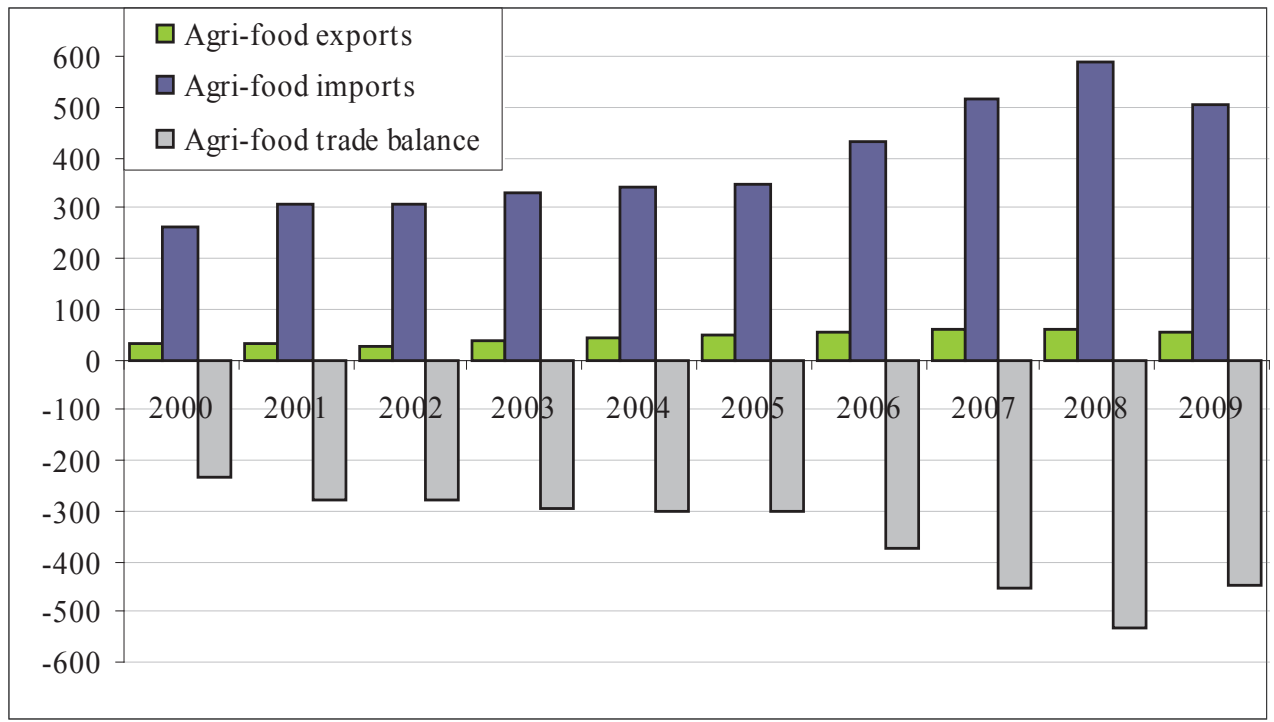

The good performance of exports has contributed to narrowing the trade deficit with $5.9 \%$ annually for this period.

The average coverage of imports by exports was estimated at $47.3 \%$ and this is recorded as its higher historical point. Trade exchanges recorded an increasement of 30.4\% during the first two months of the year. Exports in value continued in upward trend to accelerate during the first start of the year 2010 and expanded $66 \%$ in annual report ${ }^{3}$.

Despite this, it is worthly emphasizing that there is a considerable increase in production, increase in exports, imports, but also are increased the country's needs (so increase in consumption). Noting that domestic export is represented mostly by agricultural products.

During the year 2010 have seen an improvement in trade balance (calculate local needs from domestic production plus exports minus imports), some products of agro-processing sector. Valueadded services sector and the agricultural sector contributed positively but to a lesser extent annual increase of real GDP.

One of the strategic policies of Ministry of Agriculture, Food and Consumer Protection (MAFCP), is the promotion of agro-industry sector because the Albania's geographical location offers a trade potential, especially with the EU markets.

Albania has also entered into free trade agreements with all Balkan countries creating the opportunity for trade throughout the region.

In the agro-food industry there is a gradual development and sustainability in recent years providing an average annual increase in value of about $3-5 \%$.

Given that agricultural-livestock products and agro-processing have a considerable potential to increase export volumes, in particular the support for increased production of bio.

${ }^{3}$ Monetary Policy Report, April 2011 
Agro-industry sector productivity has increased by 4.7 in the year 2008 and 5.2 in the year 2010 (calculated as the total output value by the number of employees), however the competitiveness of agrofood industry is limited.

So $91 \%$ of cheese that is needed for a year and only $9 \%$ are imported; $89 \%$ of butter is produced in the country, $86 \%$ olive oil, $68 \%$ sausage and bacon, and about $57 \%$ natural and sparkling water ${ }^{4}$.

Table 2: Export-Import in 2000-2010

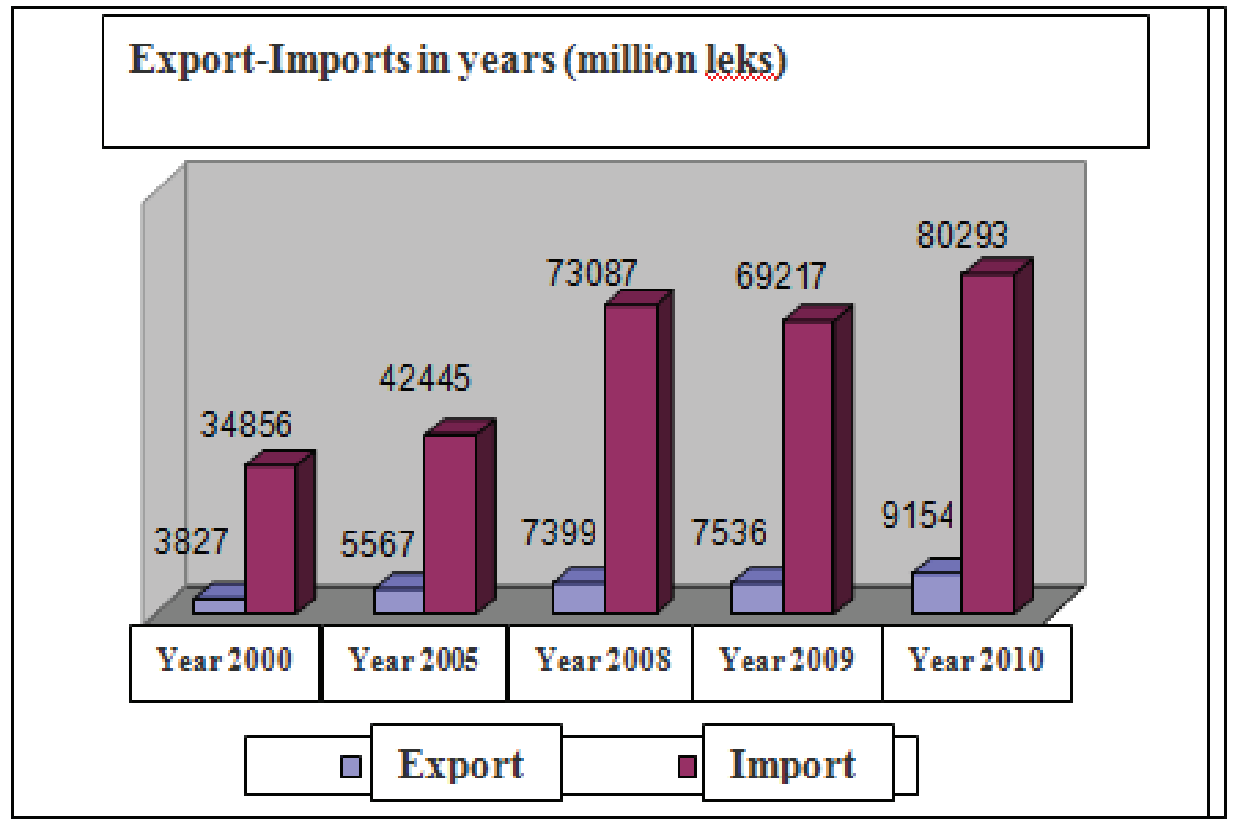

Export opportunities in Albania for agricultural products and processed have increased significantly but still are far from their real capacity.

This is mainly result of:

i. lack of marketing facilities (storage, processing, packaging of products);

ii. low standards concerning food safety;

iii. low degree of competition in the Albanian market of agricultural products because of low quality and relatively high cost of Albanian products.

The development of exports plays a very important role on improving macroeconomic indicators. The importance of export growth is seen not only to reduce the trade balance, but also to improve the quality of products and increased manufacturing skills, creation of new jobs, improving the welfare and general economic development of the country. Improving the quality of our products will positively affect the growth of exports and will increase the the level of replacing imports with locally produced products.

${ }^{4}$ Ministry of Agriculture Statistical Yearbook, 2010 


\section{Exports:}

In the year 2010, the value of exports in agricultural and food products accounted 9 I54 million leks, from which 73\% with EU countries (Italy and Greece, with greater weight); 5\% the United States; $3.5 \%$ in Turkey; and about I8\% with regional countries (Kosovo, Macedonia, etc.).

From export growth during 2000-2005 was about 45\%; from 2005-2008 about 33\%; in 2009 had only $2 \%$ growth of exports (compared with 2008); and in 2010 had increased by $22 \%$. The main products have been exported on: medicinal plants, fresh vegetables and processed; oily seeds, watermelons, internal livestock, canned fish, and raw hides.

If you look at the data of 2010 noted that the largest share of export value of agro-industry occupies about $54 \%$, followed by agriculture and livestock $35 \%$ to I $\%$.

\section{Imports:}

In 2010, imports of agricultural product services accounted for about 80293 milion ALL, of which $54 \%$ of the EU countries (notably Italy and Greece). The products that play the most important role on imports were: fresh vegetables, wheat, vegetable oils, cereals, flour or starch, edible mix, alcoholic beverages, tobacco and processed tobacco.

Greater importance to the value of imports of processed products are occupied (agro-industry) by about $62 \%$, followed by agricultural products and livestock products $26 \%$ to $12 \%$.

\section{Some of the reasons for restricting Albanian exports:}

- Deficiency and low levels of agricultural production and agro-processing industry;

- Lack of marketing facilities (storage, processing, packaging of products);

- Low standards on food safety;

- Low degree of competition in the Albanian market of agricultural products because of low quality and relatively high cost of Albanian products.

Table 3: Structure of Export 2005 - 2010

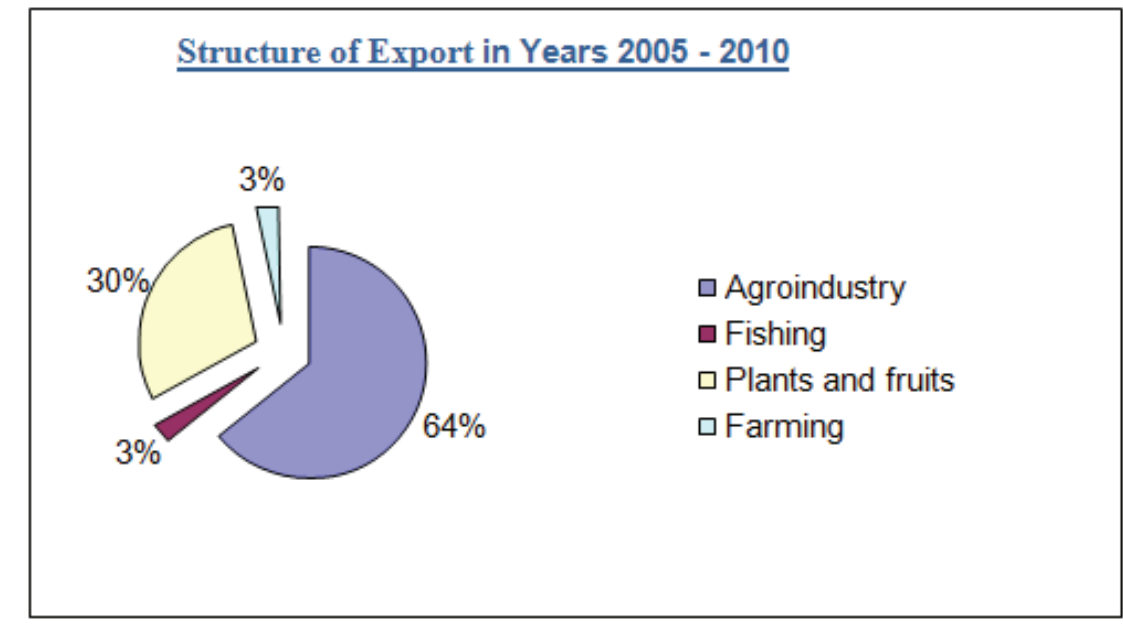


Low competitiveness of our products mainly is associated with low quality, but also with food insecurity and high cost of production. These are the main factors limiting exports.

This confirms the fact that the products exported have a little more demand for food safety, or guarantee them a higher degree (canned fish, medicinal plants, tobacco, watermelon, etc.)

\section{Instruments to promote exports}

Some of the instruments for promoting and increasing exports are:

- Competitiveness Fund for promotion of exports;

- Support scheme in agriculture;

- Exposure of the products through organizing National and International Fairs;

- Improvement of network marketing, etc.

Competitiveness Fund for promotion of exports implemented by Albanian Investment Development Agency (AIDA). Albanian Investment Development Agency as a public agency responsible for the implementation of private sector development and particularly for SMEs, promoting export and foreign direct investment in Albania, was established and operates under the Law No. I0303, dated on I5 July, 2010 "On the Establishment and organization of the Albanian Investment Development Agency".

Besides these activities, it also manages promotional and fund program competitiveness. Financial support is provided through the implementation of a grants scheme for cost-sharing to a maximum of I million per company exporters but not more than $50 \%$ of the total cost. Support is provided for activities such as product certification, implementation of quality management system, market research, sales missions, conformity assessments required to penetrate the target market, representation abroad (costs related to finding agents and distributors, participation in fairs as a visitor, participation in trade fairs as exhibitors, promotion, publishing and design promotional materials for the target market). Costs need to be approved in accordance with standard procurement procedures, use of specific consulting services, customized product (including coverage and labeling, creating web pages, etc.).

Support Scheme in Agriculture: The second instrument supporting the scheme was applied to the state budget funds by the Agency of Agriculture and Rural Development (AZHBR) in the Ministry of Agriculture, Food and Consumer Protection in the framework of support for agriculture. This scheme directly affects the growth of production; support agro-processing businesses, therefore increase the possibility of exports. Also this scheme is a financial support to cover the cost of certification of organic agricultural products and intended for export.

Organization of fairs: Serves as one of the main instruments in terms of encouraging exports and promoting businesses and products of the Albanian regional and international market. So for years planned a fund from the Ministry of Agriculture Food and Consumer Protection budget for participation in these events.

Only for 2010 are based on the participation in international fairs 5 and 6 national regional fairs. This in close cooperation with business associations, financial institutions, donor projects, local governments, etc. Positive impact not only affected the revenue growth of businesses through the conclusion of new contracts, knowing the latest trends, technologies, etc., But above all in creating a stable image of Albanian businesses and products.

Improvement of marketing: Establishment of wholesale and retail markets, slaughter of cattle collection centers; refrigerating rooms; have been some interventions to improve quality and storage products to a possible increase in their exports. Farmers have begun to orient the marketing of products, the selection of seeds. These measures have given high yields. 


\section{Conclusions}

To reach a sustainable economic development, firstly we should take into consideration that exports is a very important factor on this development.

Export opportunities in Albania for the agricultural products and also for the processed products have been increasing significantly, but still they are far from their real capacity.

This is mainly due to some factors:

a) Lack of marketing facilities ( storage, processing, packaging of products);

b) Low standards related to food safety;

c) Low level of competitiveness in the market of the albanian agricultural products due to low quality and relatively high cost of the albanian products.

The importance of increasing export is not only seen for reducing the trade balance, but also for improving quality of the product and increasing production capability, opening new jobs, improving the wellfare and also for the economic development of the country.

Increasing the quality of our products will have a positive impact on export growth and will increase the rate of imports with the locally produced products.

\section{Bibliography}

Strategy and business development investments (2007-2013)

Monetary Policy Report, April 201 I

Ministry of Agriculture Statistical Yearbook, 2010

Sector Strategy of Agriculture and Food (SSBU), 2007 - 2013

National Plan for Implementation of the SAA 2009 - 2014

Institute of Statistics 